\title{
Being an institutionalized elderly person: meaning of experiences based on Heidegger's phenomenology
}

\author{
Ser-pessoa-idosa institucionalizada: sentido do vivido à luz da fenomenologia Heideggeriana \\ Ser-persona-anciana institucionalizada: sentido de lo vivido a la luz de la fenomenología Heideggeriana
}

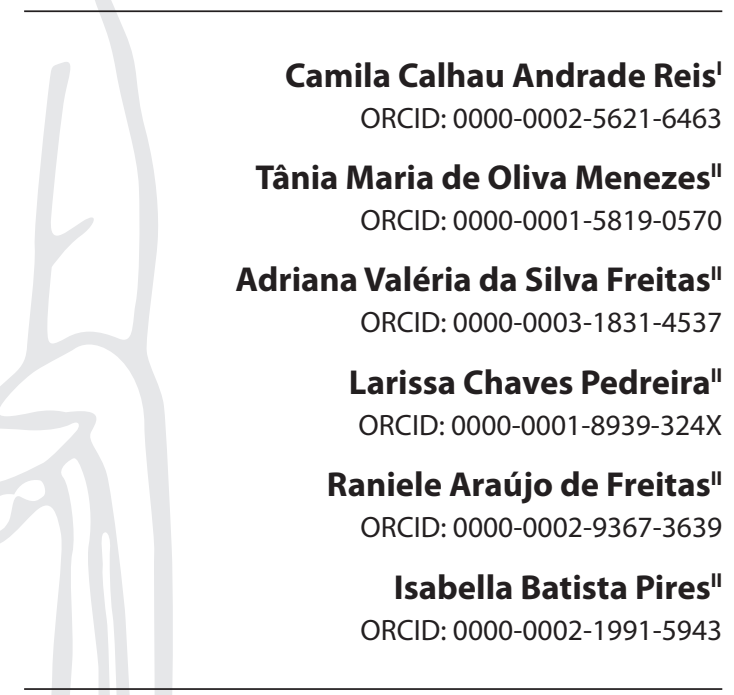

'Universidade Federal do Sul da Bahia. Itabuna, Bahia, Brazil. "Universidade Federal da Bahia. Salvador, Bahia, Brazil.

How to cite this article: Reis CCA, Menezes TMO, Freitas AVS, Pedreira LC, Freitas RA, Pires IB. Being an institutionalized elderly person: meaning of experiences based on Heidegger's phenomenology. Rev Bras Enferm. 2019;72(6):1632-8. doi: http://dx.doi.org/10.1590/0034-7167-2018-0763

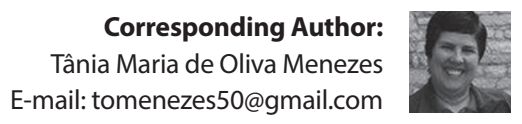

Submission: 09-27-2018 Approval: 04-21-2019

\begin{abstract}
Objective: Analyze the meaning of being an elderly person living in a long-term institution. Method:Qualitative study based on Martin Heidegger's thought. Twelve phenomenological interviews were conducted with people aged over 60 years living in a long-term institution for the elderly in the city of Itabuna, Bahia, Brazil. Results: The units of meaning identified were: experience of progressive loss of autonomy and independence, perception of living in an institution as an inevitable circumstance; and being-with becoming being-alone/ being-lonely. After the identification of ontic aspects and hermeneutical understanding, the unit of meaning was constructed: meaning of being an elderly person living in a longterm institution. Final considerations: The ontological needs referring to being an elderly person remain forgotten. As we are ontic and ontological, limited care to the ontic instance indicates deficiencies in institutionalization. Improvements are required to ensure the right to age with quality of life to this population.

Descriptors: Elderly; Institutionalization; Long-Term institution for the Elderly; Nursing philosophy; Nursing.
\end{abstract}

\section{RESUMO}

Objetivo: desvelar o sentido de ser-pessoa-idosa vivendo em instituição de longa permanência. Método: pesquisa qualitativa fundamentada no pensamento de Martin Heidegger. Foram realizadas 12 entrevistas fenomenológicas com pessoas acima de 60 anos que residem em uma instituição de longa permanência para idosos na cidade de Itabuna, Bahia, Brasil. Resultados: as unidades de significados desveladas foram: vivência da perda progressiva de autonomia e independência; percepção da ida à instituição como trajetória circunstancial inevitável e o ser-com torna-se ser-só/ser-solitário. Após apreensão dos aspectos ônticos foi possível a compreensão hermenêutica e a construção da unidade de significação: o sentido de ser-pessoa-idosa vivendo em instituição de longa permanência. Considerações finais: as necessidades ontológicas, as quais atentam para o ser-pessoaidosa seguem esquecidas. Como somos ôntico e ontológico, o cuidado limitado à instância ôntica sinaliza deficiências na institucionalização. Melhorias são necessárias para garantir a esse grupo populacional o direito de envelhecer com qualidade de vida.

Descritores: Idoso; Institucionalização; Instituição de Longa Permanência para Idosos: Filosofia em Enfermagem; Enfermagem.

\section{RESUMEN}

Objetivo: desvelar el sentido de ser-persona-anciana viviendo en una institución de larga estadia. Método: investigación cualitativa con base en el pensamiento de Martin Heidegger. Se realizaron 12 entrevistas fenomenológicas con personas mayores de 60 años que residían en una institución de larga estadia para ancianos en la ciudad de Itabuna, Bahia, Brasil. Resultados: se obtuvieron los siguientes significados: vivir la pérdida progresiva de la autonomía e independencia; percebir la ida a la institución como un camino circunstancial inevitable y ser-con se convierte en ser-solo/estar solo. Tras aprehender los aspectos ónticos, se hizo posible la comprensión hermenéutica y la construcción de la unidad de significación: el sentido de ser-persona-anciana viviendo en institución de larga estadia. Consideraciones finales: las necesidades ontológicas que tienen en cuenta el ser-persona-anciana siguen olvidadas. Como somos óntico y ontológico, el cuidado limitado a la instancia óntica señala carencias en la institucionalización. Son necesarias mejoras para que les garantice a ese grupo de población el derecho al envejecimiento con calidad de vida.

Descriptores: Anciano; Institucionalización; Hogares para Ancianos; Filosofía en Enfermería; Enfermería. 


\section{INTRODUCTION}

Accelerated aging of populations is a common characteristic in demographic dynamics all around the world ${ }^{(1)}$. In Brazil, the number of elderly people rose from 3 million in 1960 to a little more than 30 million in 2017, an increase of $1,000 \%$ in almost 60 years ${ }^{(2)}$, implying social support to meet the biopsychosocial and cultural needs of these people.

In the history of society, family has always been considered as care provider to an aging family member. However, given the changes in social, cultural, institutional and economic spheres, it is increasingly difficult to develop this task. In this context, referral to a long-term institution for the elderly (LTIE) emerges as one of the most common non-family care strategies in recent years ${ }^{(3)}$.

According to RDC resolution no 283, LTIEs are "governmental or non-governmental institutions of residential character for the collective home of persons aged 60 or over, with or without family support, in the condition of freedom, dignity and citizenship"(4). The health care model of LTIEs seeks to value independence, preserve self-esteem and respect the individuality of the elderly ${ }^{(5)}$. Despite consolidated concepts and objectives, negative aspects of the experience of institutionalization implicitly influence most definitions and perceptions regarding the functions of LTIEs ${ }^{(6)}$.

Referral to an LTIE may represent an abrupt break of affective bonds for the elderly, which will contribute to loneliness, anxiety, and sadness. After this event, many elderly persons have nervous system diseases and psychic disorders such as depression ${ }^{(7-10)}$. Affective bonds here do not only refer to family ties, but to a life context. Old people are living stories, social beings full of subjectivity and collective memories of the social groups to which they belong, they are society assets ${ }^{(11)}$.

Therefore, a study using a phenomenological approach with this population segment is relevant, since aging dynamics in Brazil and the growing number of elderly people in LTIEs lead to the challenge of understanding them in their existential and subjective dimension to ensure proper decisions to fulfill the needs of this group.

Considering that being does not consist in a mere presence in the world ${ }^{(12)}$, this study analyzes the meaning of being an elderly person living in an LTIE and is justified by the need to address the ontological aspects and understand the being-there and being-in-the-world of the institutionalized elderly person by analyzing the meaning of being. This way, it will be possible to define sensitive, effective and current care strategies for institutionalized elderly people. The following study question was defined: What is the meaning of being an elderly person living in a long-term institution for the elderly?

\section{OBJECTIVE}

To analyze the meaning of being an elderly person living in a long-term institution.

\section{METHOD}

\section{Ethical aspects}

This study observed the ethical requirements of Resolution 466/12 of the National Health Council, which addresses research involving human beings ${ }^{(13)}$. Before starting building the information and the interviews, an informed consent form was distributed to all participants to obtain formal acceptance of study participation, explain study risks and benefits, and ensure anonymity and the possibility of withdrawal at any moment of the interview, without any damage or loss to participants. To preserve their identities, each participant chose the name of a favorite flower or plant, and these names were used as their respective identifications. This study was approved by the Research Ethics Committee from Universidade Federal da Bahia, protocol no 1.813.613.

\section{Study type}

This is a phenomenological study based on a Heidegger's approach and his book Being and time $e^{(12)}$, and using $\mathrm{COREQ}^{(11)}$. A method of reflection was adopted that allowed a perspective of things as they emerge in consciousness, without explanations or justifications, but with questions and descriptions that seek to capture the essence and meaning ${ }^{(15)}$. This article was developed from a doctoral thesis titled $O$ sentido de ser-pessoa-idosa vivendo em instituição de longa permanência à luz da fenomenologia heideggeriana.

\section{Study site}

This study was conducted in an LTIE located in the city of Itabuna, south of Bahia, from January to August 2018. Of philanthropic origin, this LTIE was founded in April 1988 and is currently supported by community donations, pension of elderly residents, Sua nota é um show de solidariedade - a program of the Secretariat of Labor and Social Action (Setras), and a fund from the state government to the municipal administration of Itabuna.

This LTIE has operated for 30 years, and has become a reference facility for care provision to elderly people in conditions of vulnerability, currently housing 98 people from different municipalities in the south region of Bahia. Its social relevance for Itabuna and surroundings justifies its selection as the study site.

\section{Study participants}

Twelve institutionalized individuals, aged 60 years and over, participated in the study. The inclusion criteria were: 1. elderly person who has lived in the institution for at least four months, which is sufficient for the elderly to attribute meanings and significations to experiences before and after institutionalization; 2. Preserved cognitive and oral language expression conditions assessed via mini mental state examination (MMSE).

MMSE is the most frequently used cognitive screening tool in the world. It is a neuropsychological test that easily analyzes the cognitive state of adults and elderly people ${ }^{(16)}$.

This is a phenomenological study, so the authors were not concerned about numbers, but the depth of understanding and discussion of collected information ${ }^{(17)}$. The field activity was conducted with the analysis, so the interviews were suspended when the knowledge acquired was enough to fulfill the study objective and analysis the phenomenon under investigation. 


\section{Data collection and organization}

Phenomenological interviews were used as a technique for data collection, which seeks to access and understand the experiences of a human being, and identify the meanings of being-in-the-world ${ }^{(18)}$.

A phenomenological interview is an open dialogue between two persons, in which the phenomenon is conveyed through speeches of the participant about a past or current experience. Then, the participant rescues the speech already processed, based on what the phenomenon is for him/her, that is, the experiences that are coded and stored in the consciousness ${ }^{(19)}$.

For data collection, initially, a starting point was prepared, called ambiance - a fundamental preparation in phenomenological studies. Heidegger points out that, in order to reach the essence of the phenomenon, it is necessary to practice a convenient type of access, or in other words, a convenient starting point ${ }^{(12)}$.

For every elderly person, five visits were planned on average: four for ambiance and one for the phenomenological interview. Ambiance visits were opportunities to establish intersubjectivities with the elderly through informal conversations that included explanations about the study and invitation to participate. It also allowed interviewers to understand the dynamics of LTIE operation and the routine of each elderly person to identify the best days and times for the interviews.

The interviews took place in the study site, in a reserved area that ensured information privacy and secrecy. All interviews were performed in the afternoon, as the intense routine of morning care (breakfast, baths and dressings) could interrupt the interviews.

A digital recorder was used to ensure reliable transcription and interpretation of the information, as well as a field log to record complementary data, perceptions and description of each meeting and interview conducted. The visit time depended on how every elderly person was feeling, without time limits. Recordings ranged from 12 to 35 minutes.

\section{Analysis of interviews}

After the interviews, a comprehensive analysis of the experience was conducted based on Heidegger's analytical-hermeneutic thought. This strategy does not allow an immediate understanding of the being-an-institutionalized-elderly-person. Two methodical moments had to be analyzed to define the facets of an existential dimension from the daily life of the study participants.

The first methodical moment is the result of a vague understanding called ontic instance ${ }^{(12,20)}$. It started at transcription and reading of acquired information. In this step a phenomenological speech was built from the identification of essential structures and meanings expressed by the study participants. The experiences shared by them showed meanings and information of their own inner self ${ }^{(21)}$. Therefore, speeches were precisely transcribed, so that expressions and singularities were not lost.

The second moment is called ontological instance. It represents an interpretive or hermeneutic understanding, which shows an unknown who, the meaning of being ${ }^{(12)}$. With this analysis, the units of meaning were 'transformed' into a unit of signification. Interpreting means assessing a phenomenon as it is. In other words, the meanings expressed from a vague and meditative understanding lead to a unit of meaning, which supports an interpretation, an existential construction that lies behind, located in the ontological dimension of the phenomenon ${ }^{(22)}$. This analysis allowed the definition of a unit of meaning: the meaning of being-an-elderly-person living in an LTIE.

\section{RESULTS}

\section{Characterization of elderly people participating in this study}

Twelve elderly people participated in the study - six female and six male participants. Mean age was 79.6 years, in an age group ranging from 61 to 93 years. Six were over 80, including two persons over 90 . Nine of them were not married and six had no children. Regarding religion, 11 were Catholic. They had been living in that LTIE from 4 months to 7 years. Regarding their educational level, in general, the participants did not study at a school or studied a few years, four of them were illiterate. Only one participant had complete higher education.

Attentive and exhaustive reading of the experiences shared by the participants, combined with an analysis of the context around them, allowed the development of units of meaning to identify the meaning of being-an-elderly-person living in an LTIE. In this process, the elderly person living in an LTIE showed that he/she: 1 . Experiences a progressive loss of autonomy and independence; 2 . Perceives his/her moving to an LTIE as an inevitable circumstance; 3. Being-with becomes being-alone/being-lonely.

\section{Progressive loss of autonomy and independence}

Loss of autonomy and independence was reported by interviewed elderly as a factor for moving to an LTIE and a consequence of the institutionalized life, enhancing such loss.

You had to see when I used to do things, I used to sew, and now I have nothing to do here and they wouldn't let me do it. I've already sewn a lot, I've made a nightgown, embroidery, I made them to sell. The worst thing is the disease. When a person is healthy, he/ she can go anywhere. But sick, unable to go out? Are you kidding? (Pansy, 87 years old, female, single)

I used to do everything before I came here. Now everyone does everything for me. They don't let me do anything. Yesterday I had a fight here because the boy wanted me to do what he wanted. Son, you can't do what you want, no, do what I want. I do what you want if I want it too. Now I think my independence has been impacted. (Tagetes patula, 77 years old, female, single)

The speeches of Pansy and Tagetes patula show that due to chronic health conditions, they stopped performing routine activities of pleasure and occupation over time, such as cooking, sewing and going to the bank, as well as decisions about what do. They begin to compare 'what I used to do' with 'what I no longer can do,' generating suffering.

First, I wake up, they give me a bath, wash my hair and everything. The nurse gives me a shower and then she dresses me, they use 
perfume and cream on me. If I wake up at night I pee, but I sleep with a diaper. (Clove, 93 years old, female, single)

Last week, I didn't have a shower before 10, 11 am. Everyone had a shower and then breakfast, and I couldn't eat breakfast because they hadn't given me a shower. (Dahlia, 76 years old, female, widow)

You can only take one shower a day but I had two a day. Changing clothes only once a day. (Orchid, 61 years old, male, divorced)

The elderly people living in this institution undergo situations they had never imagined they would have to experience, such as relying on other people to perform daily activities, following rules, procedures and schedules established by professionals.

I need to be more independent. I mean, I need people to know that I need to be independent. Because everybody wants to give orders to me and I allow it. But I don't want it. (Tagetes patula, 77 years old, female, single)

Tagetes patula reports that, in some situations, her opinions and wishes are ignored and, against her will, she does what is imposed to her.

\section{Moving to an LTIE as an inevitable circumstance}

For the elderly people interviewed in this study, moving to that LTIE was an inevitable circumstance: special care was required as a result of aging and the impossibility of living as before. There was no other option, except moving to the LTIE:

Like it or not, this is the place you have to come, you have to stay here. Relatives can't take care, they may help, bring something, some money, but taking care is difficult. A nephew doesn't want it, he won't stop to take care of an uncle. (Petunia, 78 years old, male, single)

When they told me, I didn't want to, but I came here because I needed it, unlike those who healthy legs and feel nothing wrong, so let's do it. (Rose, 73 years old, female, single)

The reasons for moving to an LTIE include circumstances shared by the being-in-the-world of the interviewed people: marital status (widow/widower or single), no children, family losses, living alone, and health conditions that impacted their autonomy/independence.

They [children] had to work and no one else could take care of me at home. Then I had to come here, because I can't stay at home alone, what can I do? It's the only good place you have. My daughter and my son-in-law brought me here. (Dahlia, 76 years old, female, widow)

I had nobody else to stay with. My niece works, her children work, my sister is sick, I've lost my brother. Then I moved here, right after my mother died. My niece brought me here. (Pansy, 87 years old, female, single)

My daughter found a vacancy here. (Daisy, 82 years old, male, single)
The speeches show that children and/or relatives (brother/ sister, uncle/aunt, nephew/niece) of the elderly participants are busy with work and other obligations, i.e., being-there immersed in the surrounding world implies routine life that impacts beingwith. Then, they have no time available to take care of the other or the time available is insufficient to fulfill the needs of the other, and, as observed in the speeches, the institutionalization process was mediated by close relatives, who somehow are responsible for the elderly care.

\section{Being-with becomes being-alone/being-lonely}

The daily life of institutionalized elderly people has been mostly based on isolation, confinement and memories, according to the speeches reproduced below. They said they missed home which, in this circumstance, goes beyond the meaning of a house, and missed beloved people. Then, while before the institutionalization the elderly people were inserted in social contexts and relations that involved home, work, family and other intersubjectivities, today they are a being-there living in a world of memories.

Today I would like to have someone with me, sometimes, talking to me, a woman, one of those that were once mine. I miss that so much. (Daisy, 82 years old, male, single)

Ah! I have a special person [smiles], it's the teacher, she works at Banco do Brasil, we've had a relationship 14 years. I've dreamed about her until now. I feel lonely. (Orchid, 61 years old, male, divorced)

These days I was crying here because I wanted to go home: "I want to go home, I want to go home", crying as a child, but I couldn't go. (Tagetes patula, 77 years old, female, single)

About family relations, some of them talked about receiving visitors, characterizing them as unpredictable occasions, which can take days, weeks or months to happen. Not knowing when and if they will receive relatives and beloved ones can generate expectations and anxiety. The following speeches reflect these feelings and show the institutionalized elderly persons experience uncertainties that are typical of life in the LTIE:

Someone [from the family] visits once in a while, but it takes a long time, two months, three months. (Petunia, 78 years old, male, single)

I miss my son because I haven't seen him again. He came here about 15, 20 days ago. I called him today, he will probably come today. I'm waiting. (Orchid, 61 years old, male, divorced)

My aunt said that she'll come here tomorrow, she'll come tomorrow, she has to come! (Tagetes patula, 77 years old, female, single)

I don't receive visitors, except people who stay here and bring things. I'm here, someone comes in, talks to me, then I answer. (Clove, 93 years old, female, single)

I don't receive family visitors. Strangers come to see me. (Rose, 73 years old, female, single) 
Relatives don't come here. Also, I don't care so much about relatives. Not even my grandchildren come. So I receive visitors like this, from you and other people, they talk to me, they're young. (Anthurium, 92 years old, male, widower)

The statements of Clove, Rose and Anthurium show they do not receive visitors or only receive strangers, even having relatives who live in the city, such as children, grandchildren and nephews/nieces. These speeches show a being-with who becomes being-alone/being-lonely.

In my bedroom, we don't even talk. I share the room with four men. Every one remains in his own place, quiet. I have my TV set, I watch my TV, the other one has a radio, he listens to the radio outside the room, I don't talk to almost anyone. (Orchid, 61 years old, male, divorced)

They put me in a room with that, what's her name? Clove! I'm terrified, she stays there, she doesn't talk. She doesn't talk to me, she does not say anything. I only talk to Dahlia, this girl here [points to another old woman] and these nurses. (Pansy, 87 years old, female, single)

So far, my contacts are gradual. You came here, I started talking to you, but there's no close friendship, right. For now, it's only good morning, good afternoon, good night and I just go ahead with my life. (Lily, 86 years old, male, single)

Also about being-alone/being-lonely, sharing spaces or having several people physically close every day does not ensure a company or bond, i.e., staying-with does not mean being-with.

\section{DISCUSSION}

For Heidegger, a human being here is understood as being-there (Dasein), who will change, denoting openness and movement, and exists only as a being-in-the-world ${ }^{(23)}$. In this perspective of existing and being-in-the-world, the moment a person arrives at a LTIE, being-an-elderly-person changes to being-an-elderlyperson living in an LTIE, and the meaning of being is continuously 'adjusted' with every experience.

This adjustment of the existence of interviewed beings, along with the circumstances described as reasons for moving to an LTIE, are linked with what Heidegger calls facticity. For the philosopher, facticity is "the designation for the ontological character of 'our own' being-there, this being-there on every occasion"(23). That is, facticity is seen as a basic element of Dasein, which appears itself on the horizon, bringing new possibilities of being-in-the-world.

The experience of progressively losing autonomy and independence is, therefore,'a result' of the facticity of being-there, that is, of an existential condition full of unforeseen, uncontrollable and sometimes not understood possibilities, including health and illness circumstances. In this sense, when, in an ontic instance, the speeches show the elderly people perceive the act of moving to an LTIE as an inevitable circumstance, they also experience the facticity of being-there thrown into the world, regardless of their will, and with no options.

Regarding facticity, in the 'destinations' of the elderly people, the experience of institutionalization is linked with that being that comes to them within their being-in-the-world ${ }^{(12)}$. This understanding is related to what older people refer to as 'no option.'

With the experience of institutionalization, the meaning of being-an-elderly-person living in an LTIE is presented as a beingthere attached to facticity. Such experience echoes in Dasein what Heidegger calls existential angst. For the philosopher, existential angst expresses Dasein thrownness into a world that cannot be dominated. Therefore, it is the expression of a entity for the being thrown into an essentially strange, disturbing, restless and even hostile world ${ }^{(12,24)}$. In this world, Dasein does not feel comfortable, but rather strange, vulnerable and restless confronting its own being ${ }^{(24)}$.

The anguish experienced by being-an-elderly-person living in an institution appeared in the speeches about progressive loss of autonomy and independence and moving to an LTIE as an inevitable circumstance. Life in an LTIE, as a new world, has continuously allowed experiences which, instead of reducing existential anguish, otherwise enhance it all the time. It was clearly seen in the speeches showing loneliness, homesickness, and uncertainty.

The basis of being-in-the-world is defined by with, considering the world is always shared with others. The world of presence is a shared world. Then, a human being is an entity that exists only as being-with-others, and therefore cannot be understood outside the relations that constitute one's world ${ }^{(12,22)}$.

Absent or inexistent family members and friends in the daily life of most elderly people interviewed in this study show being-with as being alone experiencing the institutionalization. "Even being alone of presence is being-with in the world. The other may be absent only in being-with and for a being-with. Being-alone is a deficient way of being-with"(12).

Even with elderly persons sharing a room with other people and establishing, on a daily basis, intersubjectivities with caregivers, visitors and other institutionalized elderly people, their speeches had complaints of being lonely. That is, even when, in an ontic instance, circumstances pointed to a being-with, they showed a being-alone. This is because, most of the time, institutionalized elderly people do not know each other and suddenly they need to share a room with strangers. That is forced sociability, which can lead to the feeling of not belonging to that place, isolation and, consequently, loneliness ${ }^{(25)}$. In this regard, Heidegger reports that "being-alone is not eliminated because other men are near me. The presence may be alone even when these other men are simply given"(12).

\section{Study limitation}

The limitation of this study is related to non-generalization of results for the entire institutionalized elderly population, since they represent elderly people living in an LTIE in the country region of Bahia. However, the results allow an in-depth discussion of the information collected and can be applied to elderly people experiencing situations that are similar to those of the study participants.

\section{Contributions to the area of nursing}

The results of this study can support health professionals in the development of less reductionist and more sensitive and effective care strategies. In addition, this study supports (re-)structuring of health policies and strategies to fulfill specific 
needs, thus favoring re-signification of practices and perceptions regarding the elderly persons living in LTIEs.

\section{FINAL CONSIDERATIONS}

Supported by Heidegger's phenomenology, the authors concluded that facticity of the being-there thrown into the world without options led the elderly people to progressive loss of autonomy and independence, experience LTIE as an inevitable circumstance, and become being-alone/being-lonely.

The statements of elderly people helped understand that, currently, health care for the elderly living in LTIEs is focused on meeting the physiological needs of the elderly entity and is restricted to the ontic instance. Ontological needs remain forgotten. Since we are ontic and ontological beings, the limited care to the ontic instance indicates deficiencies in the institutionalization process.

The existential anguish of the being-an-elderly-person is enhanced when this person starts living in an LTIE. In an entangled and reversed movement of implications, the existential anguish of the being-in-the-world, experienced in an ontological instance, has an impact on the ontic instance through biological, psychological, social, and spiritual expressions of every elderly entity.

Nurses and other health professionals involved in the provision of care to institutionalized elderly persons should frequently perform a self-reflection exercise about their performance, questioning: What dimension of the elderly person has been reached by the care provided by me? The ontic dimension, which involves an entity of science manifestation? The ontological dimension, which considers the facticity of the being-there and its possibilities of changing in the world? Or both?

Health professionals should open up to see what, at first, is not visible. Only after that, they will be able to broaden horizons for ontological care by understanding that they do not deal with institutionalization, since it does not exist in itself, but rather, they deal with elderly persons in their different modes-of-beinginstitutionalized. Then, the opportunities for improvements in health care are expanded and, consequently, the right to age in an LTIE with dignity and quality of life.

\section{REFERENCES}

1. Organização Mundial de Saúde (OMS). Resumo: relatório mundial de envelhecimento e saúde [Internet]. Genebra: OMS; 2015 [cited 2018 Sep 17]. Available from: https://apps.who.int/iris/bitstream/handle/10665/186468/WHO_FWC_ALC_15.01_por.pdf;jsessionid=D20ECA236E 79D0EBD13A36F51607B743? sequence $=6$.

2. Paradella R. Número de idosos cresce $18 \%$ em 5 anos e ultrapassa 30 milhões em 2017. IBGE - Agência de Notícias [Internet]. 2018 [cited 2018 Aug 21]. Available from: https://agenciadenoticias.ibge.gov.br/agencia-noticias/2012-agencia-de-noticias/ noticias/20980-numero-de-idosos-cresce-18-em-5-anos-e-ultrapassa-30-milhoes-em-2017

3. Camarano AA, Kanso S. As instituições de longa permanência para idosos no Brasil. Rev Bras Est Pop. 2010;27(1):233-5. doi: 10.1590/ S0102-30982010000100014

4. Agência Nacional de Vigilância Sanitária (ANVISA). Resolução de Diretoria Colegiada n 283, de 26 de setembro de 2005. Aprova o Regulamento Técnico que define normas de funcionamento para as Instituições de Longa Permanência para Idosos. Diário Oficial da União [Internet]. Brasília; 2005 [cited 2018 Sep 19]. Available from: http://portal.anvisa.gov.br/documents/10181/2718376/RDC_283_2005_COMP. pdf/a38f2055-c23a-4eca-94ed-76fa43acb1df

5. Coimbra VSA, Silva RMCRA, Joaquim FL, Pereira ER. Gerontological contributions to the care of elderly people in long-term care facilities. Rev Bras Enferm [Internet]. 2018;71(suppl 2):912-9. doi: 10.1590/0034-7167-2017-0357

6. Fagundes KVDL, Esteves MR, Ribeiro JHM, Siepierski CT, Silva JV, Mendes MA. Long stay institutions as an alternative for protecting the elderly. Rev Salud Pública. 2017;19(2):210-4. 10.15446/rsap.v19n2.41541

7. Alves-Silva JD, Scorsolini-Comin F, Santos MA. Elderly in long-term institutions: development, living conditions and health. Psicol Reflex Crít. 2015;26(4):820-30. doi: 10.1590/S0102-79722013000400023

8. Güths JFS, Jacob MHVM, Santos AMPV, Arossi GA, Béria JU. Sociodemographic profile, family aspects, perception of health, functional capacity and depression in institutionalized elderly persons from the north coastal region of Rio Grande do Sul, Brazil. Rev Bras Geriatr Gerontol. 2017;20(2):175-85. doi: 10.1590/1981-22562017020.160058

9. Azevedo LM, Lima HHG, Oliveira KSA, Medeiros KF, Gonçalves RG, Nunes VM, et al. Perfil sociodemográfico e condições de saúde de idosos institucionalizados. Rev Bras Pesq Saúde. 2017;19(3):16-23. doi: 10.21722/rbps.v19i3.19560

10. Frade J, Barbosa P, Cardoso S, Nunes C. Depressão no idoso: sintomas em indivíduos institucionalizados e não-institucionalizados. Rev Enf Ref. 2015;serIV(4):41-9. doi: 10.12707/RIV14030

11. Valença TDC, Reis LA. Memória e história de vida: dando voz às pessoas idosas [Internet]. Rev Kairós. 2015 [cited 2019 Jan 24];18(2):265-81. Available from: https://revistas.pucsp.br/kairos/article/view/27001

12. Heidegger M. Ser e tempo. 10ª ed. Petrópolis: Vozes; 2015.

13. Ministério da Saúde (BR). Conselho Nacional de Saúde. Resolução n 466, de 12 de dezembro de 2012. Aprova as diretrizes e normas regulamentadoras de pesquisas envolvendo seres humanos e revoga as Resoluções CNS n. 196/96, 303/2000 e 404/2008. Diário Oficial da União [Internet]. Brasília; 2012 [cited 2018 Sep 18]. Available from: http://bvsms.saude.gov.br/bvs/saudelegis/cns/2013/ res0466_12_12_2012.html 
14. Tong A, Sainsbury P, Craig J. Consolidated criteria for reporting qualitative research (COREQ): a 32-item checklist for interviews and focus groups. Int J Qual Health Care. 2007;19(6):349-57. doi: 10.1093/intqhc/mzm042

15. Sebold LF, Locks MOH, Hammerschmidt KSA, Fernandez DLR, Tristão FR, Girondi JBR. Heidegger's hermeneutic circle: a possibility for interpreting nursing care. Texto Contexto Enferm. 2017;26(4):e2830017. doi: 10.1590/0104-07072017002830017

16. Melo DM, Barbosa AJG. O uso do Mini-Exame do Estado Mental em pesquisas com idosos no Brasil: uma revisão sistemática. Ciênc Saúde Colet. 2015;20(12):3865-76. doi: 10.1590/1413-812320152012.06032015

17. Reis CCA, Sena ELS, Menezes TMO. Experiences of family caregivers of hospitalized elderlies and the experience of intercorporeality. Esc Anna Nery. 2016;20(3):e20160070. doi: 10.5935/1414-8145.20160070

18. Guerrero-Castañeda RF, Prado ML, Kempfer SS, Ojeda-Vargas MG. Momentos del proyecto de investigación fenomenológica en enfermería. Index Enferm [Internet]. 2017 [cited 2019 Jan 24];26(1-2):67-71. Available from: http://scielo.isciii.es/scielo. php?script=sci_arttext\&pid=S1132-12962017000100015\&lng=es

19. Guerrero-Castañeda RF, Menezes TMO, Ojeda-Vargas MG. Characteristics of the phenomenological interview in nursing research. Rev Gaúcha Enferm. 2017;38(2):e67458. doi: 10.1590/1983-1447.2017.02.67458

20. Braga TBM, Farinha MG. Heidegger em busca de sentido para a existência humana. Rev Abordagem Gestalt [Internet]. 2017 [cited 2019 Jan 25];23(1):65-73. Available from: https://dialnet.unirioja.es/servlet/articulo?codigo=5921968

21. Oliveira ALB, Menezes TMO. The meaning of religion/religiosity for the elderly. Rev Bras Enferm. 2018;71(suppl 2):770-6 [Thematic Issue; Health of the Elderly]. doi: 10.1590/0034-7167-2017-0120

22. Peixoto AJ, Holanda AF, (Orgs.). Fenomenologia do cuidado e do cuidar. Curitiba: Juruá; 2011.

23. Heidegger M. Ontologia: hermenêutica da facticidade. Petrópolis: Vozes; 2012.

24. Sá AF. Entre a angústia e a dor: um diálogo entre Martin Heidegger e Ernst Jünger. Nat Hum [Internet]. 2016 [cited 2018 Sep. 20];18(1):14456. Available from: http://pepsic.bvsalud.org/pdf/nh/v18n1/v18n1a08.pdf

25. Bruinsma JL, Beuter M, Leite MT, Hildebrandt LM, Venturini L, Nishijima RB. Conflicts among institutionalized elderly women: difficulties experienced by nursing professionals. Esc Anna Nery. 2017;21(1):e20170020. doi: 10.5935/1414-8145.20170020 